\title{
Character Education Learning Model as the Form of Assurance on Children's Rights in Early Childhood
}

\author{
Hudriyah Mundzir ${ }^{1 *}$, Moechammad Sarosa ${ }^{1}$, Suhari $^{2}$ \\ ${ }^{1}$ Electrical Engineering Department, State Polytechnics of Malang, East Java, Indonesia \\ ${ }^{2}$ Faculty of Teacher Education, University of PGRI Adi Buana Surabaya, East Java, Indonesia
}

*Corresponding Author: Hudriyah Mundzir, Electrical Engineering Department, State Polytechnics of Malang, East Java, Indonesia

\begin{abstract}
The growth of preschool educational institutions focused on intelligence without considering the emotional and spiritual quotient has influenced parents' opinion that a qualified child is a child who is highly intelligent. They did not consider the children' character education. Thus it is not surprising that today's children tend to be violent. This study tries to offer a learning model in which a character educations designed for three age groups, which are childhood, youth, and adulthood, using materials refer to the prophetic character: Siddiq (truthful), Amanah (trustworthy), Tabligh (deliver) and Fatonah (smart). With examples of the prophet's commendable behaviors and having taught from the early childhood, children are expected to follow the prophet' example so that they have a well-mannered, self-confidence, persistent, and intelligent character; in which have been built since childhood. The phasing of character education aims to form the child' soul to mature, having dominant maturity traits and emotionally stable as the form of children's rights assurance. There are three influential components in character education: house, school, and environment, in which those three components each has an inseparable role. By guaranteeing that the three components can work well, instill the positive character to children is a form of child rights guarantee.
\end{abstract}

Keywords: character education, phasing of education, children's rights, prophetic character

\section{INTRODUCTION}

Education is an essential factor that determines the progress of civilization. Right and proper education will create a significant and progressive civilization. Children are the next generation whose role is to build culture. School is the learning of knowledge, skills, and habits of a group of people passed down from one generation to the next through teaching, training, or research. Education often occurs under the guidance of others, but also allows a self-taught.

Development of children's potential is strongly influenced by coaching and education given by parents, communities, and educational institutions. It can develop naturally without being influenced by the environment, however, the development cannot be optimal, on the contrary, if the children's potential is stimulated by their environment, the potential will develop more optimal. Due to this reason, children should be given coaching and education suited to its potential so that it can develop optimally.

Based on Indonesia's Constitution No. 20 the Year 2003 on National Education System, article 3 states that the National Education aims to develop students' potentials to become a man of faith and devoted to God Almighty, noble, healthy, knowledgeable, skilled, creative, independent and become a democratic and accountable citizens.

\section{Problem Formulation}

How is the character education learning model as the form of children's rights in early childhood assurance?

\section{DISCUSSION}

\subsection{Definition of Character Education}

Character education is a conscious and earnest effort of a teacher to teach values to their students [1]. The parties who provide the character education are family, school, and community. Character 
education should be continuously done holistically from all the educational environment; which are family, school, and community. According to Miftahudin, character education during the early childhood in family aims to establish, during the teenage years in schools aims to develop, while during adulthood in college seeks to strengthen. The tasks of educators are providing an excellent learning environment to establish, build and enhance the students' character [2].

As stated in the National Education Law No. 20, 2003 Chapter 1 Article 1 that education is a conscious and planned effort to create a learning environment and process so that learners are actively developing their potential to have the religious, spiritual power, self-control, personality, intelligence, noble morality and their required skills, which is also needed by the community, nation, and state (Act No. 20 of 2003 on National Education System). On the other hand, education develops based on a wide range of educational theories. Rousseau, one of the education personage, states that the naturally given education produce and help the quality development of happiness, spontaneity, curiosity and their concept of unfolding which is the innate nature of the child towards the future (growth experience). Furthermore, Pestalozzi states that the family environment is considered as the center of activities for mothers in educating children. Pestalozzi believes that the way to recognize a variety of concepts is through various experiences such as counting, measuring, feeling and touching. The teacher is the most critical aspect of the learning experience, not the learning subject itself. Thus there is a need for educational institutions to assist children in learning, supported by their social environment [3].

Character education is done by the habituation to behave positively and avoid negative behaviors. The Character Education Partnership constructs 11 principles of effective character education, namely: (1) promote the values of the code of ethics based on positive character; (2) define the character comprehensively on thinking, feeling and behaving; (3) using an affective, comprehensive, intensive and proactive approach; (4) create a caring school community; (5) provide opportunities for students to perform and develop moral action; (6) develop a challenging and meaningful curriculum for helping students to success; (7) drive the students' intrinsic motivation to learn and become a reasonable person in their environment; (8) encourage all teachers to become a professional and a moral party in the learning process; (9) stimulate the growth of transformational leadership to develop lifelong character education; (10) involve family members and the community as partners in the education of character; (11) evaluate the character of the school community to obtain information and design the next character education efforts[4].

Implementation of all the 11 principles of character education should become part of the school program, not only the responsibility of one subjects, one teacher or one-time activity. Implementation of the integrated character education could be done through the school rules and regulations, the learning process during the class and extracurricular activities. Educators must provide exemplary behavior/character for the students.

The Character Education, Guidance, Life skills from (www.livewiremedia.com) identifies that a man of good character is a man who has the following characteristics: 1) trustworthiness: the ability to be relied on as honest or truthful; 2) Respect: a feeling of courtesy for someone or something elicited by their skills, qualities, or achievements. 3) Responsibility: the state or fact of being accountable for a given task or duty 4) Fairness: be fair and prudent in making decisions 5) Caring: showing concern for others, helpfulness 6) Citizenship: shows the nationalism, love the country/institution, loyal, discipline in abiding by the rules/law 7) Honesty: the quality of being honest and open 8) Courage: has the attitude of courage, bravery, or love challenges 9) Diligence: has the attitude of persevering, tenacious, unyielding and hard work 10) integrity: the quality of being honest and having strong moral principles, consistent.

Similar to the character traits previously explained, the Indonesian Heritage Foundation (IHF) develops a model called "Character-based Holistic Education." The curriculum used is "Characterbased Integrated Curriculum." The curriculum aims to improve the whole human dimension. There are nine character foundations in the curriculum, namely: (1) the love of God and all His creatures; (2) independence and responsibility; (3) honesty / trustworthy; (4) respectful and polite; (5) generous, helpful and cooperative / collaborative; (6) confident and hardworking; (7) leadership and justice; (6) kind and humble and; (9) tolerance, peace, and unity [5]. 
Such education is in contrast with the one Rasulullah SAW taught, in which we need to be tawazun (balance) both in the life in this current world and later after death. Rasulullah built four prophetic characteristics, which are divided into three intelligence categories, emotional, spiritual, and intellectual. The four prophetic characteristics, Siddiq (honest), Amanah (trusted), Tabligh (conveying), and Fathonah (intelligent) is the characteristics that should be planted early on every child. The process should be done consistently in stages, not all at once, and focused on the target characters, which is the Islamic way in character building. In the early stages, the behavioral attitude was built first than wording language. Nonetheless, Islam teaches us to balance intellectual and emotional intelligence since children are expected to be ulilalbab, people who serve Allah and society using their intelligence [6].

Early childhood education, which is intended for children under six years, is the fundamental education to build the children' character. Children in this age tend to be more accessible to mold and imitate, which is why it is essential to develop their moral, religiosity, social awareness, communication skill, as well as the physical growth, intelligence, and language ability. The education chosen should make the prophetic character as the primary goal for character and attitude building, since it is based on a positive role model suited for the underage children [6].

\subsection{Character Education Model on each Aging Stage (Comprehensive Approach)}

Character education is given gradually based on age ranges. Implementing character on the children in their early childhood should be done based on the phase of the child's age. It could be done by observing the child's ability to receive information determined by the age [6].

The phases of implementing character education consist of:

a. Early Stage

At this stage, the family is the main factors that determine a person's character. It is the stage of equipping a child with the proper attitude.

\section{b. Elementary School Stage}

At this stage, the character education implementation is done by integration. Previous researches on the development of character education resulted in several models of character education in children. The data of character education model at elementary school period was obtained from the study of character education model development done by Umi Faizah, Zidniyati, Anasufi Banawi and Baharudin sponsored by postgraduate research grants [7]. Character education has been integrated into Indonesian studies through illustrated stories and role play. It also has been integrated into science and social studies through character-based science learning models, and ARCS (attention, relevance, confidence, and satisfaction) approaches conducted by Banawi and Baharudin. The results show that the use of illustrated stories and role play could improve the practice of honesty, patience, and worship, as well as the Indonesian language skills (listening, reading and speaking) effectively.

Character-based science learning model ARCS approach (attention, relevance, confidence, and satisfaction) proved to be effective to increase the values of honesty, responsibility, and acts of worship, and science/social learning outcomes. The implementation of character education is done both inside and outside the class in a variety of activities, including at home and the community by involving parents.

\section{c. Youth Stage (Junior and Senior High School)}

Character education model for teens studied from the previous research. Mulyani has developed an integrated model of directive speech act in implementing important moral and national character on students [8]. The directive speech of principals, educators and academic staff to students can be classified into three categories: commands, requests, and suggestions. The command is shown in the actions such as forbid, warn, instruct, admonish, urge and require. The request is expressed in begging, hoping, asking, urging and inviting. The suggestion is conducted in advising, encouraging, offering, inviting and recommending. The command is integrated with role play, simulations, and group discussions. The request is integrated into an exemplary action, simulation and role play. The suggestion is integrated into social activities, field trips and problem-solving. 


\section{d. Adult Stage (College)}

Establishing good values in college student takes a long time through habituation. Characters in adults as college students are already rooted and difficult to change through common learning strategies. However, lecturers still must remind, tell and advise the students not to do negative actions. Character stabilization is also a part of the responsibility of the academic advisory lecturer.

The proper character education for an adultis through increasing awareness for positive behavior and self-evaluation. Character education is more effective if it emerges from their consciousness and not under others' influence. Character education could be implemented through lectures and religious talk, seminars, discussions, media, movies, scientific papers on character education, learning from others' life experiences, and so on. People with negative character could turn out to have a positive one after they were faced with the problems of life and learn from the lives of others who are experiencing the problem.

Character education should consider the stages of effective learning. Bloom made five stages of affective learning, which are acceptance, feedback, rewards, organization, and internalization [9]. For children, affective learning can be done until the third stages, which is the reward stage. On teenager, it could go one step further, which is organization. Whereas in adults, affective could be learned until the internalization stage.

The affective learning process that can shape personality traits could occur through the following mechanisms:

1. Receiving; at this time, children received their first message/advice on the right and wrong values in human behavior. Children will successfully be human with the positive character if they listen to the given message/advice on the life values.

2. Responding; once children listen to the message/advice to the good a wrong values, they would give a corresponding response. Children who potentially have a definite character will abide by the ethical values received in the previous stage.

3. Valuing; after the child abides by the positive values in their behavior, children have started to apply the right values in their daily lives even though no other party orders them.

4. Organizing; when the child is used to implement positive values, he will be able to choose the good values among others.

5. Internalizing; occurs when the values have become a philosophy of life so that people will not be affected by external factors. Positive/negative behavior has penetrated into themselves, consistent, and could be predicted so that it is difficult to change.

The perfect child is a mature child, with a prominent maturity and emotional stability [10]. Hence, it could be concluded that there are three influencing components of a character education studies, which are the home, school, and social environment. Home as the first education circle focused on five cases, which are educating by example, by habituation, by counseling, by caring, and by punishment. On the other hand, school environment means that teachers should have the educators' nature such as sincerity, loyalty, knowledgeable, forgiving, and aware of the responsibility. The last is the social environment that focused on the friendship, which includes friends at home, neighborhood, mosque, and school.

\section{CONCLuSion}

Character education is an activity to implement positive character traits in children. It is done by a phasing model based on the child's age. The phasing of character education is done to shape a mature, has dominant maturity traits and emotionally stable child. There are three influencing components on implementing character education, namely home, school, and social environment. Home as the first education circle focused on five cases, which are educating by example, by habituation, by counseling, by caring, and by punishment.

On the other hand, school environment means that teachers should have the educators' nature, such as sincerity, loyalty, knowledgeable, forgiving, and aware of the responsibility. The last is the social environment that focused on the friendship, which includes friends at home, neighborhood, mosque, 
and school. There are three influential components in character education: house, school, and environment, in which those three components each has an inseparable role. By guaranteeing that the three components can work well, instill the positive character to children is a form of child rights guarantee.

\section{ACKNOWLEDGMENTS}

This research is supported by the Directorate General of Higher Education, Indonesia through the "Leading Applied Research Universities" (PTUPT) grants.

\section{REFERENCES}

[1] Majid A. and Andayani D., Pendidikan Karakter Perspektif Islam. Bandung: PT Remaja Rosdakarya, 2011.

[2] Miftahudin, "Implementasi pendidikan karakter di SMK Roudlotul Mubtadiin," in Seminar Nasional: Strategi dan Implementasi Pendidikan Karakter Bangsa di Tingkat Satuan Pendidikan , Bogor, 2010.

[3] Patmonodewo S., Pendidikan Pra Sekolah. Jakarta, Indonesia: Erlangga, 2008.

[4] Lickona T., Schaps E., and Lewis C., CEP's Eleven Principles of Effective Character Education. Washington, DC: Character Education Partnership, 2003.

[5] Megawangi R., "Strategi dan Implementasi Pendidikan karakter di PAUD," in Seminar Nasional: Strategi dan Implementasi Pendidikan Karakter Bangsa di Tingkat Satuan Pendidikan , Bogor, 2010.

[6] Hudriyah M., Sarosa M., and Chalim A., "Implementation of Prophetic Characteristics in Early Childhood Character Education," in International Conference on Islamic Civilization (ICIC), Social Faculty of UIN, Malang, 2014.

[7] Zuhdi, Darmiyati, and Muhsinatun, "Pengembangan Model Pendidikan Karakter Terintegrasi Dalam Pembelajaran Bidang Studi di Sekolah Dasar," e-journal Cakrawala Pendidikan Universitas Negeri Yogyakarta (UNY), May 2010.

[8] Mulyani, "Model Integrasi Tindak Tutur Direktif Dalam Penerapan Pendidikan Ahlaq Mulia dan Karakter Bangsa Bagi Pelajar di SMA," Jurnal Penelitian Inovasi dan Perekayasa Pendidikan, vol. 2 (1), pp. 225 248, August 2010.

[9] Bloom, Krathwohl , and Marsia , Taxonomy of educational objectives. New York: Longman., 1964.

[10] Ulwan A.N., Tarbiyatul Aulad fil Islam. Solo: Insan Kamil, 2012.

\section{AUTHOR'S BIOGRAPHY}

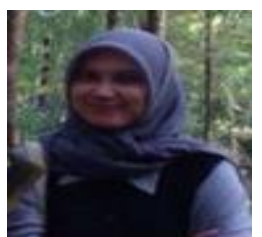

Hudriyah Mundzir is lecturer in Digital Telecommunications Networks Study Program of Electro Engineering Department of State Polytechnicsof Malang, in Pancasila and Civics Education. She received the Magister of Law from BrawijayaUniversity of Malang, Indonesia,Her current research covers the study and development of learning media related to her fields of expertise.

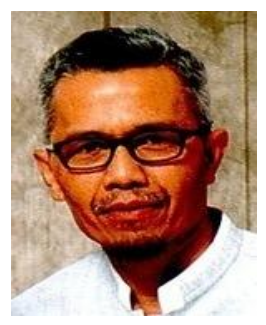

Moechammad Sarosa received the M.T. and doctor degrees in computer technology from BandungTechnology Institute, Indonesia, in 2002 and 2007, respectively. $\mathrm{He}$ is a lecturer in Electro Engineering Department of State Polytechnics of Malang. His current research interests lies in ICT development and applications, artificial intelligence and embeded system. And currently working on learning media development, including web based and mobile based learning media.

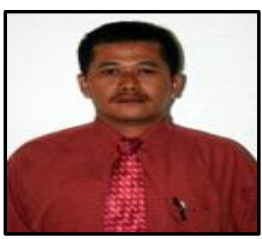

Suhari is a lecturer in Pancasila and Civics Education Study Program at PGRI AdiBuana University, Surabaya, Indonesia. His fields of expertise include Pancasila Education (Ideology), Moral Education, Civics Education, and Character Education. His current research covers the study and development of learning media related to his fields of expertise.

Citation: Hudriyah Mundzir, Moechammad Sarosa, Suhari. " Character Education Learning Model as the Form of Assurance on Children's Rights in Early Childhood."International Journal of Humanities Social Sciences and Education (IJHSSE), vol 5, no.9, 2018, pp. 43-47. doi: http://dx.doi.org/10.20431/23490381.0509007.

Copyright: (C) 2018 Authors. This is an open-access article distributed under the terms of the Creative Commons Attribution License, which permits unrestricted use, distribution, and reproduction in any medium, provided the original author and source are credited. 